\section{Reciprocal Teaching and Genre-Based Approach Combination: A Proposed Strategy in Business English Classes}

\author{
Sugeng Hariyanto \\ Brawijaya University, Malang
}

\begin{abstract}
Reciprocal teaching (RT) is a teaching procedure for Abstract: Reciprocal teaching comprehension involving direct instruction, modeling, feedback and repeated practice in four cognitive strategies, namely questioning, clarifying, summarizing, and predicting. The focus of questioning, clarifying, summarizing, and prew heaning can be constructed with language and train them to make use of language to fulfill their needs. This approach proceeds through 4 steps: preparation, modeling, joint construction, independent construction, plus one additional step, publishing. Reciprocal teaching approach (RT) is used because it can incorporate speaking activities. The texts are selected based on the genre that will be used in the work sites, namely in the office setting. This article presents how to apply reciprocal teaching and genre-based approach to teach Business English at non-English Department of university level. This proposed strategy has been tried out at Business Administration Department of State Polytechnic of Malang. A sample lesson plan is given at the end of this article.
\end{abstract}

Key words: reciprocal teaching, genre-based approach, lesson plan, business english.

In Indonesian colleges ESP courses are typically offered one meeting per week ( 2 x 50 minutes duration) to Non-English Department students. One class consists of $30-45$ students. So far, the materials are characterized by reading passages-either taken by the teachers from various sources or provided by ready-made textbooks-and grammar practice. The reading passages are about the concepts or theory of the main field of studies. The way of teaching it is following the textbook's sequence, i.e. reading and answering comprehension questions. Writing assignment is usually given at the end of each topic in the form of writing expository writing related to the topic of the reading passage. With such an approach, Speaking seems neglected. With the use of reciprocal approach the reading comprehension activities is maintained and speaking activities is brought in. This article presents how to jointly apply reciprocal teaching technique and genre-based approach in ESP classes offered to Business Administration students.

The appendix is a lesson plan designed based on it. It is for English for Specific Purposes (ESP) for the students of Business Administration departments.

\section{THE THEORETICAL BASES FOR THE PROPOSED STRATEGY}

Using this model, the class will not follow the textbook's sequence. Students are involved in every step of instructions. Reading is still taught, and so is writing. Every unit starts with reading, which is taught with reciprocal teaching (RT) technique.

The writing dealt with in this lesson plan is not expository writing, but the texts typically occurring in the workplace. The type of the text to write is related to the reading text and is selected based on the specific genre. Then, writing session is given using genre-based approach

With the application of genre-based approach using workplace texts, the students are familiarized with and trained to write documents as they will have to in their profession later. Such idea is offered by Joyce (1992: 4) with a different context of students, who go to the classes especially to improve their job-related language.

By incorporating workplace texts, the oral language is not neglected at all. In real workplace people talk, read, and write. They talk about the text they have to read or write, and after reading they can even talk more (Joyce, 1992: 4). If such situation can be transferred into the classroom, oral language development can be promoted naturally without worrying to choose specific topics. The topics will be the same as the topics of the texts 
The following are the principles or theoretical bases for reciprocal teaching and genre-based approach to teaching writing.

\section{Reciprocal Teaching}

Reciprocal teaching (RT) is a technique in teaching reading in which the teacher helps students to employ cognitive strategy in a reading process. The procedure itself was designed by Anne Marie Palincsar, from Michigan State University and Anne Brown, from the University of Illinois. To be involved in a RT session, students are grouped into small heterogeneous groups.

In its original procedure, RT is characterized by: (a) a dialog between students and teacher (or a group leader), (b) "reciprocal" interactions where one student acts in response to the other and (c) structured dialog using four strategies or steps: questioning, summarizing, clarifying, predicting. Thus, each student has ample opportunity to practice using the strategies while receiving feedback from other group members.

These four strategies are the main steps in any RT session. Each step helps students to comprehend meaning from the text and monitor whether they do understand what they read. Usually the four-step cycle takes place for one part of a text.

In questioning session, students generate questions. Here they should think of what they don't know, need to know or would like to know about a part of a passage. Generating questions helps to promote purposeful reading.

In summarizing, the students are given an opportunity to identify, paraphrase, and integrate important information in the text and communicate it in a comprehensible manner. The summary may center on gists, key words, themes and topic sentences.

Clarifying emphasizes that the goal of reading is to make sense of the text When students ask for clarification, they become more aware of potential problems that hinder their comprehension. The potential problems can be new vocabulary, unclear referent words, and unfamiliar or difficult concepts. Recognizing these blocks to understanding signals the reader to reread, read ahead, or ask for help. In this step, any reference books are useful. The teacher should be ready to come to the rescue instantly or later.
In predicting session, students are required to hypothesize about what the author might discuss next in the text. This step demands students to utilize given information and background knowledge. Predicting encourages thoughtful, strategic reading, too. This provides a purpose for reading: to confirm or disapprove their hypotheses.

\section{How a Typical RT Session Takes Place}

RT technique uses the idea of scaffolding. Before the students are let to have a group discussion using RT, the teacher first gives an example of how to conduct a discussion using RT. The students are encouraged to observe, to copy, and then to participate. As they get more confident and competent, the teacher's responsibility in the process is withdrawn gradually. This kind of giving and withdrawing help is called scaffolding (Ng, 1990: 14). In other words, scaffolding refers to situation where the teacher provides a supportive context in which the students can gradually acquire the skills the tutor has (Seok Dawn, 1989: 15)

After every group is competent enough to run an RT session, it can start the reading process. First, the group reads the predetermined paragraphs silently. The discussion leader raises questions to the group. The group members respond to it. The members can also raise additional questions. The leader then summarizes the text and asks if other members would like to elaborate upon or revise the summary. Clarifications are given here by any member of the group. Then, before moving on to the next part of text, the group generates predictions. Another member will be assigned to be the leader for the next part. This process continues until the whole passage is discussed (Ng, 1990: 15; Westera, 1993: 99).

\section{Why RT is Selected}

According to Westera (1993:100) this technique is suitable for English as a Second Language (ESL) students. He states further that it can develop students' reading interest, give opportunity to extend language practice as it also needs discussion, and improve students' reading comprehension skills and academic achievement.

A web page writes that teachers who utilize reciprocal teaching with text materials promote learning because reciprocal teaching actively 
engages students in the process of "constructing meaning" while promoting the conscious use of effective comprehension strategies. " The page states further:

This strategy is especially effective with content/expository text

While reciprocal teaching has been successfully applied with students in the primary grades through college, the research indicates that this procedure may be most effective with less proficient readers. This is understandable since the four component strategies of reciprocal teaching are designed by readers

In short, RT is proposed to be used here because it gives the students opportunity to extend language practice into reading and speaking at the same time. These are the two important skills needed in the workplace (offices). In addition, the choice is also motivated by the fact that nonEnglish Department students are less proficient English readers as compared to those of English Department.

In the proposed lesson plan, RT technique is done during the first week. By the end of the session, teacher asks the class if there is something left unsolved during the discussion. Then using the same technique the teacher deals with the problems classically. Finally, at the end of the lesson, students would have comprehended the passage. (It means the first and second objectives are achieved. See lesson plan for further details.) Their schemata, or knowledge of the field, about business meeting is built, or at least enriched. This also prepares students for the following sessions. This technique is applied at the first half of the first week's session.

\section{Genre-based Approach}

Genre approach to teaching writing is adapted from a functional approach to language (Shi: 1995: 153). Such approach examines how language enables man to do things, such as sharing information, giving instruction, entertaining, arguing, etc. Here, genres are redefined according to their functions and purposes. The focus of this approach is to

\footnotetext{
See: Error! Bookmark not defined.
}

show students how meaning can be constructed with language and train them to make use of language to fulfill their needs (Derewianka, 1990:3).

Such teaching approach is applied in Primary schools and High Schools in New Zealand, Australia, and Singapore. In the application the teaching process proceeds along a curriculum cycle. Such cycle was first introduced by Derewianka (1990) and is divided into 4 steps: preparation, modeling, joint construction, independent construction, plus one additional step, publishing (Derewianka, 1990: 6-9; Shi, 1995: 155).

The most well known model is the one developed by Literacy and Education Research Network (LERN), which consist of three phases: modeling, joint negotiation of the text, and independent negotiation of the text (LERN, 1990a: 11). This differs from Derewianka's in the sense that it does not include the preparation phase. This is may be caused by the nature of the main genres taught with this model. The genres are called schools genres including reports, procedures, expositions, and explanation (Hyon, 1996: 699-700).

In the field of adult English education, New South Wales Adult Migrant English Service (NSW AMES), also adopts genre-based approach to teach the adult immigrants (Hyon, 1996: 700). Yet, the genres are different from the ones dealt with in schools. The genres are identified from the workplace and called workplace genres. According to Joyce (1992: 16), they include signs, procedural texts, forms, circular, messages, and visual representation. Another book cites 10 text types, namely telephone message, memos, forms, instruction, minutes of meetings, reports, work orders, evaluation, and proposal (Belfiore and Burnaby, 1995: 50). With these kinds of genre and students, the first step in Derewianka's teaching cycle gets its importance. It is sometime renamed as "building knowledge of the field" (Joyce, 1992: 44-47), as sometimes the field of occupation is new for the learners.

The lesson plan designed here adopts the teaching cycle proposed by Derewianka (1990) and especially Joyce (1992). With this teaching cycle, at the first step, i.e. building knowledge of the field, students are familiarized with the cultural context, participants, and social purposes of the genre that will be dealt with. The vocabulary related to the text and context is also introduced. The interaction focus is teacher-class, and student-student (Joyce, 1992: 44-45). Reading comprehension activity 
ming reciprocal teaching technique may serve a good activity in this step interaction focus and by reading comprehension as it has such kinds of knowledge of the field can be built as long as the the first 40 minutes of the first week.

In the second step, modeling, teacher introduces the genre by

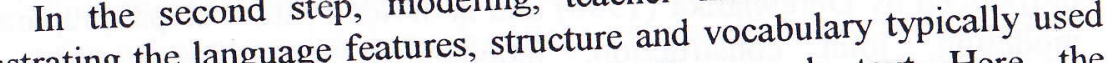
illustrating the language features, structure anple text. Here, the in the text, and text organization using the sample first week. interaction focus is teacher to class. This is done in the text together with the

In joint construction step, the students write the text the teacher. One of help of the teacher based on specific task prepared additional support for the the important purposes of this step is to provide additional sus of classroom learners before independent construction. The focus (in group). This interaction is, therefore, teac

is done in the third week.

After that in the independent construction step, the the knowledge of the supposed to construct a the students are given opportunity to genre taught previous ills independently. (See Derewianka, 1990 6-7 apply knowledge and skills independently (Ssroom hours within Joyce 1992: 44-47). This step is done one week's duration.

step offered by Derewianka is substituted with haring and discussing step. Publication of such genre may not be for the publishers or readers. Even though the last step is

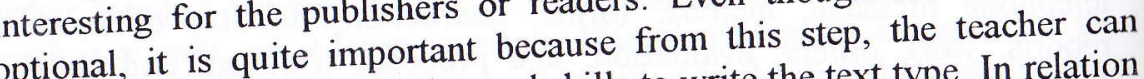

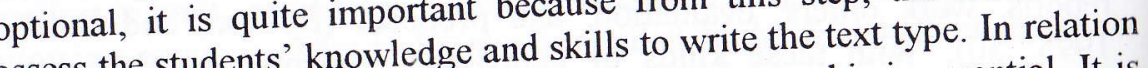
assess the students kn objectives of ESP lesson, this is essential. It is

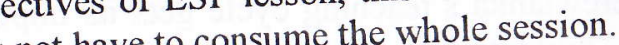
done in the third week. It does not have to consume the who in nature.

The teaching cycle adopted here is actually flexible in mat is Teacher may choose to start at any step or even omit a step in a way-705). In the lesson plan, the whole steps are included because the students are quite new at the field of "business meeting". If the students wave the knowledge first step could be omitted because all managers must have the know of "business meeting".

\section{A NOTE FROM THE CLASSROOM}

This strategy has been tried out at the Business Administration Department of State Polytechnic of Malang (Polytechnic of Brawijaya University) for Business English Subject at the fifth semester (in 2000). It was noted from the try out that, at first the students were confused as reciprocal teaching technique was new for them. To overcome this, the teacher needed some time to explain the procedure. Starting from the second meeting, however, everything went well. Some were actively involved in the process.

Another point is that not all of our units can be taught with this technique, such as "Business Telephoning" and "Socializing" because we hardly need any texts on the units.

\section{CONCLUSIONS AND SUGGESTIONS}

\section{Conclusions}

Based on the discussion above and the try out of this teaching strategy, it can be concluded that:

1. Teaching Business English at university level can be made more interesting by adopting reciprocal teaching and genre based approach.

2. Some topics can be dealt with this new strategy, some others are not. Topics that are possible for the strategy application are the ones that have the following characteristics: involve understanding written material.

\section{Suggestions}

Based on the discussion and the try out, the following suggestions can be made.

1. Teachers of Business English are suggested to try out this strategy in their own setting and modify the strategy to suit the local condition. The benefit of this approach is that it is more motivational to the students and the material is close to the target situation where the students will use English in their jobs.

2. Before adopting this strategy, the teachers should select and determine which of their syllabus items are potential to be taught using the 
strategy and which ones are not.

3. The teachers should explain the 'rule of the game' clearly to the students before the semester starts as it seems complicated at the first time.

4. As reciprocal teaching and genre based approach are not very popular in Indonesia, the teachers should make it sure that they understand this approaches well before applying them.

\section{REFERENCES}

Belfiore, Mary Ellen and Burnaby, Barbara. 1995. Teaching English in the Workplace. Toronto, Canada: Pippin Publishing Limited.

(1995. Entrepreneurial English: Teaching Business English through Simulation. English Teaching Forum, Vol. 33, No. 2, pp. 2-7.

Davies, Susan and West, Richard. 1989. Business English 1. Jakarta.: Binarupa

Aksara.
Derewianka, Beverly. 1990. Exploring How Texts Work. Rozelle, NSW: Primary English Teaching Association

Howe, Brian 1988. The Language of Meetings and Negotiations (Video Cassettes and Teacher's Manual). England: Longman Group UK Limited.

Hariyan Hariyanto, Sugeng. 2000. Using Reciprocal Teaching Techidelines, Vol. 22. No. 2 , Based Approach in English for Business Clas

December 2000. Singapore. SEAMEO RELC. Quarterly, 30:4, 693-722.

Joyce, Helen. 1992. Workplace Texts in the Language Classroom. New South Wales: Adult Migrant English Service.

Wesearch Network 1990a. A Genre-based Approach to Teaching Writing Year 3-6: Book 1. Introduction. Annandale, New South Wales: Common Ground.

Wearch Network. 1990b. A Genre-based Approach to Teaching Writing Year 3-6: Book 4. Theory and Practice, Annandale, NSW: Common Ground

Seok Moi. 1990. Fostering Reading Comprehension, Adult Reading Assistance. Newsmagazines, 14-18.

Shi, Jie. 1995. Reaction to Different Approaches to Writing: An Analysis of Journal Kept by the Teachers of Chinese Language in Singapore. In Tickoo, Mackhan L. (ed). Reading and Writing: Theory and Practice. Singapore: SEAMEO RELC.
School Improvement in Maryland. General: Reciprocal Teaching, Error! Bookmark not defined.

Seok Dawn. 1989. Reciprocal Teaching. Good Practice in Adult Literacy, No 3., pp. 14-18.

Westera, J. 1993. Implementation of Reciprocal Teaching of Reading Comprehension at a High School. New Zealand: University of Auckland.

Whitcomb, Alan. 1983. Comprehensive Office Practice. Surrey, England: Thomas Nelson and Sons Limited.

Zubaidi, 1999. English for Business 1. Malang: State Polytechnic of Malang. 


\section{APPENDIX 1}

\section{A SAMPLE LESSON PLAN}

$\begin{array}{ll}\text { Subject } & : \text { ESP Reading and Writing } \\ \text { Times } & : 3 \times 2 \text {-hour period (once a week) } \\ \text { Dept. } & : \text { Business Administration } \\ \text { Level } & : \text { Intermediate }\end{array}$

\section{Objectives:}

At the end of the lesson the students are able to:

a. mention the function of business meeting

b. mention the procedure of business meeting

c. write documents involved in business meeting

\section{Instructional Procedures}

\section{A. FIRST WEEK}

\section{READING/BUILDING KNOWLEDGE OF THE FIELD}

\section{(40 minutes)}

(The Reciprocal Teaching Technique is used. This whole step is the Building Knowledge of The Field for the Genre Approach Teaching on the Writing.)

MATERIAL: Reading passage about business meeting.

Instructional Procedure:

(1) Students make groups of four

(2) Teacher tells the students what they are going to do

(3) Teacher distributes reading passage

(4) Students work in groups.
Note:

1. Each group should have at least one dictionary to look up difficult words.

2. By the end of the sessions, students should know exactly what business meeting is what the procedures is who are involved in it what documents are needed and what words may come along in the topics.

(The group will discuss a part of text at one time. Teacher will decide the part. One students acts as the leader who will invite the members to involve in the: (a) raising of questions, (b) clarifying words, concepts asked by other members, (c) summarize the paragraph or group of paragraphs that have been discussed, and (d) predict what they will find in the next paragraph or paragraph groups. Another member will act as the leader for the discussion of the next part of the passage.)

\section{MODELING OF MEETING AGENDA AND MINUTES OF MEETING}

1. Discussion on Meeting Agenda (25 minutes) Instructional Procedure:

a. Teacher distributes copies of meeting agenda (as a model text)

b. Teacher asks the students to read silently

c. Teacher asks the students about:

- the function of agenda of meeting

- the writer and the addressee,

- etc.

(By that time the students should have known the answers as they have discussed about them in the reading session.)

d. Teacher and students identify the text structure and language feature for agenda of meeting

2. Discussion on minutes of meeting ( 35 minutes)

Instructional Procedure:

a. Teacher distributes copies of minutes of meeting (as a model text)

b. Teacher asks the students to read silently 
c. Teacher asks the students about: - the function of minute of meeting - who makes it

- who uses it

(By that time the students should have known the answers as they have discussed about it in the reading session.)

d. Teacher and students identify the text structure and language feature for minutes of meeting.

e. Teacher distributes some other meeting agenda and minutes of meeting and students discuss it in their own group to identify the text structure and language feature.

f. Teacher helps the group that needs it.

\section{B. SECOND WEEK}

\section{JOINT AND INDEPENDENT CONSTRUCTION}

This session is devoted to giving the students exercise to write meeting agenda and minute of meeting

I. Meeting Agenda

Instructional Procedure:

1. Teacher distributes a copy of "A manager note to his secretary in which he asks the secretary to write meeting agenda".

2. Students are asked to write the meeting agenda in groups.

3. Teacher discusses sample of the meeting agenda written by the groups in front of the class.

II. Minutes of Meeting

Instructional Procedure:

1. Teacher plays a video of a "Business Meeting"

2. Students are asked to write the minutes of meeting in group

3. Teacher discusses sample of the minutes of meeting written by the groups in front of the class.

III. At the end of the lesson, teacher assigns each group to attend any meeting or record any meeting and write the minutes.

\section{THIRD WEEK}

\section{SHARING AND DISCUSSING}

Instructional Procedure:

At the last meeting, each group presents the result of its work in front of the class and discussion follows 


\section{APPENDIX 2}

\section{A SAMPLE OF INDIVIDUAL ACTIVITY SHEET}

Name

Reading Assignment Title Date

Text Pages to Summarize (Write two or three sentences that tell what this reading was
about.) Question (Write two or three questions you might see on a test or be asked
about this reading.)

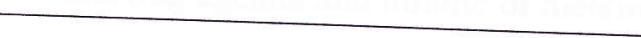
Clarify (What parts of this reading did you find confusing or do you think
a younger reader might find confusing?)

Predict (Look at the headings and pictures. What do you think the next section will be about? If you aren't sure, change the headings into
questions.)

\section{${ }^{2}$ Taken from}

(http://www.mdk12.org/practices/support_success/mspap/tips/reading/gary d/reci procal_teaching_hanout.pdf) 